\title{
Future Teachers Training to Use the Internet Network for Developing High School Students' Scientific Capabilities
}

\author{
Galina V. Makotrova, Elena N. Krolevetskaya*, Olga V. Muromtseva, Sergey A. Fadeev \\ Department of Pedagogy, Belgorod National Research University, 85, Pobeda Street, 308015 \\ Belgorod, Russia
}

\begin{abstract}
Nowadays the Professional Standard of a Teacher is being implemented in the Russian higher education. Special importance is acquired to formation of scientific and methodological readiness of pedagogical specialties students to use the Internet network. Acquired skills will prove useful in a teacher's career to develop high school students' scientific capabilities when teaching at school. The development of indicators of scientific and methodological readiness of teachers for the above-mentioned activity and research culture of high school students as well as the design and implementation of pedagogical conditions of formation of scientific and methodological readiness of future teachers in the considered context is based on the culturological approach. The research methods include survey methods, assessment of the measure of coherence between the manifestations of the indicators of the investigated scientific and methodological readiness with the help of K. Pearson criterion. A survey of Russian teachers working in profile classes of high schools showed the following items: $53 \%$ of teachers have a reproductive or adaptive level of scientific and methodological readiness to use the Internet network for the development of scientific capabilities of their high school students which were evaluated according to three criteria: motivation, technological readiness and creative activity. The article presents materials revealing the essence of pedagogical conditions for the formation of scientific and methodological readiness of students to use the Internet for developing scientific capabilities of high school students. The authors emphasize the importance of implementing the results of pedagogical research in university practice and using them in the work of students of pedagogical specialties. The identified pedagogical conditions of formation of future teachers' scientific and methodological readiness to use the Internet network in the development of scientific capabilities of high school students serve as the basis for the emergence of new pedagogical technologies.
\end{abstract}

* Corresponding author: kroleveckaya@mail.ru 


\section{Introduction}

The Internet network is actively used for high school students' education within the innovative society development. We consider the problem of the Internet network usage within high school students' scientific skills development. Such kind of development is caused by the objective processes and current requirements. In the informational environment it is observed witness decrease of knowledge value which can be gained by means of electronic networks and mail. At the same time it is sharply increasing value of abilities to select, process and use information for up-to-date problem solving as well as abilities to properly formulate informational and intellectual help inquiry for solving non-standard problems. We should pay attention to neurophysiologists' forecasts relative to the fact that the Internet stimulation, attacking sense organs, on the one hand, will adapt brain "conducting" for faster thinking, but at the same time, there can arise a threat of creative activity decrease in the result of comprehension and imagination processes reduction. Forecasts done by the English neurophysiologist S. Greenfield deserve special consideration along with the other forecasts [2]. She assumes that the sounding, bright and mobile screen world which changes rapidly in the result of clicking or touching the screen cannot help students to work out abstract concepts; there is the risk that ready-made technologies will turn education into passive entertainment, indistinguishable from other cyber life components, overfilled with perception. In her opinion, in the future visual perception will be more preferential than the facts. The commonplace training process may be subordinated to construction of free associations. Students will neither analyze the reasons of these or diverse events nor learn general concepts; they will fail to gain the knowledge system. By means of the Internet interaction students will acknowledge with some facts, but they can face shortage of time to consider and generate any creative ideas.

At the same time international research shows that students who regularly go online have higher test scores in math and reading, learn easily and have fun (Neil Selwyn, Onno Husen) [5]. Those who use computer games are more capable in self-education and have developed spatial and global thinking. (J. Beck, M. Wade) [1].

The Professional Standard of a Teacher is being implemented in the Russian higher education. Special importance is acquired to formation of scientific and methodological readiness of pedagogical specialties students to use the Internet network. Acquired skills will prove useful in teacher's career to develop high school students' scientific capabilities when teaching at school.

\section{Methods and methodology}

The development of indicators of scientific and methodological readiness of teachers for the above-mentioned activity and research culture of high school students as well as design and implementation of pedagogical conditions for formation of scientific and methodological readiness of future teachers in the considered context is based on the culturological approach. The research methods include survey methods, assessment of the measure of coherence between the manifestations of the indicators of the investigated scientific and methodological readiness with the help of $\mathrm{K}$. Pearson criterion.

\section{Results}

The high school students' scientific capabilities include three main components. They are: educational culture, research culture and future profession research orientation. Research culture of the student's personality is a basic culture component and its integrative 
characteristic defined by the combination of the following items: understanding of an integrated world image; abilities; scientific investigation skills and valuable attitude to the achieved outcomes, which ensure both self-determination and creative self-development of educational and research culture. Research culture expresses dominating properties of personality development, reflects universality of its connections with the environment, activates creative self-realization capabilities, determines informative activity effectiveness, promotes to application of scientific knowledge, abilities and skills in diverse fields of informative and practical activities. We defined four criteria of educational and research culture. They are: research motivation, scientific style of thinking, creative activity, technological readiness for investigation.

Considering future profession research orientation as high school students' ability to justify research value in the course of exercising professional activity, we have determined its following components: an involvement degree in research activity; concern in exploratory research; concern in a high school science. The degree of enumerated criteria manifestation enables to judge each criteria value and then define the development level of high school students' scientific capabilities.

Is the contemporary teacher ready to use the Internet network for high school students' scientific capabilities development? The teacher's scientific-methodological readiness is an integrative characteristic of the teacher's personality. It includes abilities and skills to use the Internet network with the purpose to develop students' scientific capabilities and creative activity manifestation. Teacher's task is to involve students in a productive informative activity in the Internet network and create valuable attitude to usage of the Internet technologies for their progress.

A survey of 340 teachers working in high schools and assessment of the degree of coherence according to $\mathrm{C}$. Pearson between the assumed indicators of the studied scientific and methodological readiness of teachers allowed us to substantiate its criteria and indicators (Table 1).

378 high school teachers from 42 regional institutions of general education took part in a computer-based testing to identify their status of scientific and methodological readiness to use the Internet network to develop scientific capabilities of high school students. The testing showed that only $5 \%$ of teachers reached the creative level. Heuristic level has $42 \%$ of testing teachers, reproductive level has $48 \%$ of teachers and adaptive level has about $5 \%$ of teachers.

Findings of a public opinion poll of the Russian schoolteachers working in profile classes stated that they preferably emphasize the following Internet advantages for pedagogical techniques implementation:

- bounds crossing due to cooperation and access to information without regard for the school location and status: access to the best libraries, museums, a possibility to listen to lectures and set problems to outstanding scientists by means of e-mail, a possibility of distant education and testing, virtual schooling, going on virtual trips and excursions;

-a wide range of opportunities for choosing means and forms of education to advance in studying various subjects;

-increase of students' motives in subjects under study due to visualization and interactivity which are used as updated material presentation form, enhancement of crosssubject links;

-improvement of educational scientific activity;

-increasing motivation to independent instruction and research work, development of critical thinking;

-development of cross-instruction methods (discussion of under study subjects by means

of Internet conferences, online help obtaining);

-development of students' abilities and motives;

-approval of students' initiative; 
-encouragement of students' and teachers' activity in learning new informational technologies;

-improvement of social development, acquaintance with a wide range of up-to-date environment problems;

-readiness for life in the informational society environment with a lifelong study orientation;

-opportunities for making a dialogue with scientists, including foreign ones through computer mail, forums and chat;

-information updating (scientific news, journal articles published prior to a printed version);

-abundance of high quality scientific and educational information;

-heuristic programs for students;

-free educational resources.

Table 1. Criteria and indicators of scientific and methodological readiness of teachers to use the Internet network for developing high school students scientific capabilities

\begin{tabular}{|c|c|c|c|}
\hline Criteria & $\begin{array}{l}\text { Motivation to use the } \\
\text { Internet network in } \\
\text { development of high } \\
\text { school students's scientific } \\
\text { capabilities }\end{array}$ & $\begin{array}{l}\text { Technological readiness to } \\
\text { use the Internet network } \\
\text { in development of high } \\
\text { school students' scientific } \\
\text { capabilities }\end{array}$ & $\begin{array}{l}\text { Creativeness to use the } \\
\text { Internet network in } \\
\text { development of high } \\
\text { school students' } \\
\text { scientific capabilities }\end{array}$ \\
\hline \multirow[t]{3}{*}{ Indicators } & $\begin{array}{l}\text { Passion for finding } \\
\text { information in the Internet } \\
\text { in the productive cognitive } \\
\text { activities of high school } \\
\text { students }\end{array}$ & $\begin{array}{l}\text { Mastering the methods of } \\
\text { searching the Internet for } \\
\text { educational purposes to } \\
\text { organize scientific research } \\
\text { of high school students }\end{array}$ & $\begin{array}{l}\text { Intensity of filling the } \\
\text { bank of methodological } \\
\text { materials from the } \\
\text { Internet for the } \\
\text { development of } \\
\text { scientific capabilities of } \\
\text { high school students }\end{array}$ \\
\hline & $\begin{array}{l}\text { Intensity of commonplace } \\
\text { things with the new } \\
\text { possibilities of the Internet } \\
\text { for the development of } \\
\text { scientific capabilities of } \\
\text { high school students }\end{array}$ & $\begin{array}{c}\text { Ability to relate the } \\
\text { pedagogical task of } \\
\text { developing the scientific } \\
\text { capabilities of high school } \\
\text { students with the } \\
\text { possibilities of educational } \\
\text { resources and technologies } \\
\text { of the Internet }\end{array}$ & $\begin{array}{l}\text { Degree of interaction } \\
\text { with teachers on the use } \\
\text { of the Internet in the } \\
\text { development of } \\
\text { scientific capabilities of } \\
\text { high school students }\end{array}$ \\
\hline & $\begin{array}{l}\text { Awareness of the value of } \\
\text { educational resources of } \\
\text { the Internet for the } \\
\text { development of high } \\
\text { school students' scientific } \\
\text { capabilities }\end{array}$ & $\begin{array}{c}\text { Knowledge of the } \\
\text { possibilities of basic } \\
\text { educational resources and } \\
\text { technologies of the Internet } \\
\text { for the development of } \\
\text { scientific capabilities of } \\
\text { high school students }\end{array}$ & $\begin{array}{l}\text { The level of use of the } \\
\text { Internet in the } \\
\text { productive cognitive } \\
\text { activities of high school } \\
\text { students }\end{array}$ \\
\hline
\end{tabular}

At the same time, it is determined the facts confirming that while using the Internet networks teachers unevenly develop the high school students' scientific capabilities components. Therefore, for example, only $52 \%$ of teachers develop high school students' understanding how significant it is to carry out research work by means of the Internet network, $26 \%$ of teachers provide their learners with solving exploratory problems technologies, $36 \%$ of teachers train solving exploratory problems techniques.

At the Pedagogical Institute appropriate pedagogical conditions were developed to form students' professional qualities within the framework of scientific and methodological readiness to use the Internet network. Among them are (1)preparation of special training manuals of how to use digital resources in the profile classes at schools; (2) intensification 
of students' activities on the use of Internet resources in the classroom and then in teaching practice; (3)involvement of students in research activities on the development of scientific skills of high school students using the Internet network; (4)creating situations of awareness of the Internet value; (5)using diagnostics of the future teachers' scientific and methodological readiness to use the Internet network to supply high school students' research skills.

The pilot testing of the teaching manual for students "The Internet network in the Development of Scientific skills of Students", the teaching manual for high school students "The Internet network for the high school Learners" showed their special interest to teaching techniques of using the Internet network in organizing high school students' work with scientific texts to develop a research problem or question, formulating the topic of the study or using the network to solve research problems during the scientific and practical conference, etc. $[3,4]$.

A number of methodological materials within the use of the Internet network in the development of scientific skills we placed on the University portal of distance courses such as "Innovative processes in education" and "Modern educational technologies". It allowed to provide prompt access to necessary information as well as to organize students' activities for writing course and diploma works, collect certain material to enrich the site on the results of teaching practice.

We paid special attention to basic concepts when forming students' abilities and skills to use the Internet network. To fix the pedagogical tasks it was proposed to study the characteristics of the manifestation of the research capabilities of students, including using the codifier, in which the universal learning activities are correlated with each of its indicators.

The student's activity in the classroom was to be continued in the extracurricular classes through research projects. Students' research work was multidimensional and involved the following items: analytical review of the literature and electronic sources on the problem, study of survey methods, statistical processing of experimental data on the problem under study, development of web-quests for work with high school students, reference tables, guidelines for students on using the Internet in cognitive activities. When fulfilling the research work students participated in the development of diagnostic material and software for processing the results of the survey of teachers and high school students on the use of the Internet network in cognitive activity. The materials of the students' research works were further used at lectures and practical classes by University teachers.

We created situations of awareness of the value of the Internet for the development of high school students' scientific skills through reflective techniques such as "crossassociation", "mind map", "unfinished sentences", etc. We developed tasks demonstrating the use of the Web by analyzing teleconferences we created for teachers of experimental schools of the region held within the project of the Russian Gymnasium Union. To assess the formation of the components of the considered scientific and methodological readiness of students we used the method of expert assessment, content analysis of students' statements as well as computer self-diagnostics. In each of the student groups we observed an equal increase in the indicators of students' scientific and methodological readiness to use the Internet network. Such dynamics testified to the systematic implementation of the identified pedagogical conditions.

\section{Discussion}

The phenomenon of "scientific and methodological readiness of teachers to use the Internet network in the research learning of high school students" and diagnostic materials created allow us to assess the level of formation of scientific and methodological readiness to use the 
Internet network both in teachers and future teachers, to identify problems of its formation and further progress. Obtained within the experimental work pedagogical conditions allow designing pedagogical technologies of training future teachers to use the Internet network in the research learning of high school students and the formation of their research skills.

The success of implementation of pedagogical conditions was ensured primarily by the implementation in the practice of teaching students the results of our pedagogical research, reflecting the problem of developing the research capabilities of students through active involvement of students in scientific work including the conditions during their pedagogical practice at school.

\section{Conclusions}

Theoretical and experimental research resulted in the following conclusions:

1.It is stated that scientific and methodological readiness of a teacher and a high school student to use the Internet network is a system formation which includes a number of teacher skills such as assess the capabilities of the Internet network to implement specific pedagogical conditions for the development of scientific skills of a high school student, to formulate specific, real and diagnostic goals of using the Internet network in developing the components of scientific skills of high school students, to determine the best ways to achieve them resulting in its creative self-realization.

2. Assessment of scientific and methodological readiness of teachers to use the Internet network for the development of scientific skills of high school students revealed that the number of teachers with a reproductive level is equal to $48 \%$. As for adaptive level of readiness it is only $5 \%$.

3. The development and successful testing of the system of pedagogical conditions within the experiment can be considered as the basis for the introduction of new pedagogical technologies.

\section{References}

1. J. Beck, M. Wade, The kids are alright: how the gamer generation is changing the workplace, Harvard Business School, Boston, Mass, 2006, 204 p.

2. S. Greenfield, One day in the life of the Brain. Neuroscience of consciousness from dawn to dusk, Piter, Saint Petersburg, 2018, 240 p.

3. G. V. Makotrova, The Internet network in the Development of Scientific skills of Students: a cultural approach, FLINTA, Moscow, 2014, 312 p. Retrieved from: https://rucont.ru/efd/246547

4. G. V. Makarova, E. N. Krolevetskaya, The Internet network for the high school Learners: textbook. manual for schoolchildren, FLINTA, Moscow, 2014, 184 p. Retrieved from: https://rucont.ru/efd/246544

5. N. Selwyn, O. Husen, The educational benefits of technological competence: an investigation of students' perceptions, Evaluation \& Research in Education Vol. 23 (2) (2010) 137-141. Retrieved from: https://eric.ed.gov/?id=EJ886090 